\title{
Pengaruh Penerapan Tata Tertib Sekolah terhadap Disiplin Belajar Siswa
}

\author{
Rohmat Alimun Taha ${ }^{1 *}$, I Nyoman Sujana ${ }^{2}$
}

1,2Universitas Pendidikan Ganesha, Singaraja - Indonesia

\section{A R T I C L E I N F O}

Article history:

Received January, 142021

Received in revised form

November, 232021

Accepted November, 24

2021

Available online December, 252021

\section{Kata Kunci:}

Disiplin belajar siswa,

faktor disiplin belajar, tata

tertib,

Keywords:

Learning dicipline factors,

students' learning dicipline,

school dicipline.

\begin{abstract}
A B S T R A K
Tujuan dari penelitian ini adalah untuk menguji adanya pengaruh penerapan tata tertib terhadap disiplin belajar siswa. Penelitian ini merupakan jenis penelitian klausal yang mencari hubungan sebab dan akibat diantara dua variabel. Terdapat dua variabel yang digunakan dalam penelitian ini yaitu variabel $\mathrm{X}$ atau tata tertib sekolah dan variabel $\mathrm{Y}$ atau disiplin belajar siswa. Penelitian ini melibatkan seluruh siswa di MA AlIrsyad Candikuning II Bedugul. Jumlah populasi dan sampel pada penelitian ini yaitu 76 orang yang terdiri dari siswa kelas X, XI, dan XII MA Al-Irsyad Candikuning II Bedugul. Pengumpulan data dilakukan dengan kuisioner yang disebar keseluruh responden terkait dengan pengaruh penerapan tata tertib sekolah. Data yang diperoleh kemudian dianalisis menggunakan analisis regresi linier sederhana. Hasil pada penelitian ini menunjukan bahwa terdapat pengaruh yang signifikan dan positif dari penerapan tata tertib sekolah terhadap disiplin belajar siswa di MA Al-Irsyad Candikuning II Bedugul. Hasil tersebut ditunjukan dengan hasil bahwa tata tertib sekolah berpengaruh sebesar $22,2 \%$ terhadap disiplin belajar siswa.
\end{abstract}

\section{A B S T R A C T}

This study aims to examine the influence of school discipline conducted on the student's learning discipline. This study is a type of clausal study which determines the relationship between both two variables. There are two variables in this study: variable X or school discipline and variable Y or students' learning discipline. This study involved the students at MA Al-Irsyad Candikuning II Bedugul. In this study, the population and samples were 76 people who were from students in grades X, XI, and XII MA Al-Irsyad Candikuning II Bedugul. Data collection with questionnaires distributed throughout the respondents is related to the influence of school discipline. The data in which the results were analyzed used simple linear regression analysis. This study's results are directed, namely the good and positive influence of school discipline where students study at MA Al-Irsyad Candikuning II Bedugul. The study proved by the results of school discipline influenced $22.2 \%$ towards the students' learning discipline.

\footnotetext{
* Corresponding author.

E-mail : rohmatalimuntaha@gmail.com (Rohmat Alimun Taha)
} 


\section{Pendahuluan}

Pendidikan merupakan salah satu hal yang wajib diterima oleh seluruh masyarakat Indonesia. Melalui pendidikan, masyarakat dapat menerima ilmu. Ilmu yang didapatkan melalui jalur pendidikan dapat dimanfaatkan untuk kesejahteraan dan keberlangsungan hidupnya dimasa kini dan dimasa mendatang. Masyarakat Indonesia dapat menempuh pendidikan melalui pendidikan formal dan informal. Kedua jalur yang dapat ditempuh memiliki tujuan yang sama sebagai sarana untuk menimba ilmu yang kelak dapat bermanfaat untuk keberlangsungan hidup. Selain itu, melalui pendidikan yang diterima, masyarakat dapat mengetahui dan mengembangkan potensi yang dimiliki. Sehingga muncul kreativitas yang membentuk karakter bangsa sesuai dengan norma yang berlaku.

Pendidikan melalui jalur formal dapat ditempuh atau diperoleh di sekolah. Sekolah dapat didefinisikan sebagai lembaga formal yang menaungi pendidikan anak. Sekolah juga merupakan tempat untuk anak bertumbuh dan berkembang menjadi individu yang lebih baik. Sekolah juga merupakan menjadi tempat untuk bersosialisasi dengan mayarakat luas, seperti yang terjadi antar siswa, guru, dan tenaga pendidik (Octavia, 2017). Dalam proses menjadi individu yang baik, terdapat tahapan yang harus dilewati. Pembentukan karakter menjadi salah satu contoh yang dapat dilakukan disekolah. Pembentukan karakter pada siswa berkaitan dengan hal-hal yang mengatur keberlangsungan mereka selama disekolah.

Pendidikan karakter merupakan salah satu hal yang penting dalam proses pembelajaran yang berlangsung disekolah. Sari dan Rofiyarti (2017) menyatakan bahwa kualitas suatu bangsat dapat dihasilkan memlaui karakter yang dibina sejak dini. Hal ini berkaitan dengan pendidikan karakter yang harus disisipkan sejak dini. Sari dan Rofiyarti menambahkan bahwa kemajuan suatu bangsa terletak pada karakter yang dimiliki oleh penerus bangsa tersebut. Sehingga untuk mempersiapkan masa depan dan kualitas bangsa yang lebih baik, diperlukan penerus bangsa yang memiliki karakter sesuai dengan norma yang ada. Pendidikan karakter pada awalmya terjadi dilingkungan keluarga yang kemudian berkembang serta meluas melalui lingkungan sekolah.

Pembentukan karakter yang dilakukan disekolah berkaitan erat dengan peraturan yang diberlakukan didalamnya. Peraturan yang diberlakukan disekolah merupakan aturan yang dirancang sedemikian rupa untuk menghindari terjadinya sesuatu yang tidak diinginkan. Menurut Hadianti (2008) peraturan yang ada disekolah yakni peraturan bagi guru-guru, peraturan bagis siswa, serta peraturan lainnya yang diyakini dapat membantu atau dibutuhkan disekolah. Peraturan yang berlaku membantu proses pendidikan yang baik, sehingga perlunya koordinasi yang baik dalam setiap prosesnya (Hadianti, 2008).

Dengan adanya pemberlakukan peraturan disekolah, khususnya pemberlakuan peraturan untuk siswa maka tingkah laku siswa dapat dikontrol dengan baik. Selain itu, aturan yang berlaku bertujuan untuk membiasakan siswa untuk berperilaku sesuai dengan norma yang berlaku serta mengarahkan siswa untuk bertingkah laku yang positif. Dalam pemberlakuannya pula, sekolah menekankan pada disiplin siswa yang berarti elemen yang ada disekolah mematuhi peraturan yang berlaku bukan dengan rasa keterpaksaan. Akan tetapi melakukan atas dasar kemauan diri sendiri untuk berubah kearah yang lebih baik.

Peraturan yang berlaku disekolah dapat disebut sebagai tata tertib sekolah. Tata tertib sekolah merupakan seperangkat aturan yang dikembangkan dan dimiliki setiap sekolah serta hasil dari pelaksaan yang konsisten terhadap peraturan yang ada (Hadianti, 2008). Pelaksanaan tata tertib sekolah yang baik dapat terjadi jika ada dukungan serta kerjasama dari setiap perangkat sekolah. Nawawi (dalam Hadianti, 2008) menjelaskan bahwa tata tertib yang ada berisi tentang tugas kewajiban siswa, larangan-larangan bagi siswa, serta sanksi yang berlaku untuk setiap tata tertib yang ada. Pernyataan ini dikuatkan oleh Nuriyah (2015) yang menyatakan bahwa tata tertib merupakan seperangkat aturan yang bersifat memaksa dengan memuat aturan tentang tugas dan kewajiban, larangan serta sanksi.

Tata tertib yang berlaku bagi siswa berguna untuk mengatur kegiatan belajar dan pembelajaran disekolah. Octavia (2017) menjelaskan bhawa untu mencaoai tujuan pendidikan yang optimal maka perlu adanya sarana pendukung, salah satu saraa pendukung yang berlaku disebut dengan tata tertib. Yuliantika (2017) melakukan sebuah penelitian tentang faktor-faktor yang mempengaruhi disiplin siswa dalam belajar menyatakan bahwa beberapa tat tertib yang berlaku disekolah meliputi tentang bagaiamana cara siswa berpakaian, kedatangan siswa, barang yang boleh dan tidak boleh dibawa ke sekolah, dan kehadiran siswa. Hal itu merupakan beberapa contoh tata tertib yang ada disalah satu sekolah, tata tertib lainnya dapat disesuaikan dengan kebutuhan sekolah serta situasi dan kondisi sekolah tersebut. Tata tertib juga harus dilaksanakan berdasarkan inisiatif dan kemauan dari diri sendiri tanpa adanya paksaan dari siapapun.

Tata tertib juga berkaitan dengan sikap siswa dalam mengendalikan diri. Pngendalian diri siswa dapat ditunjukan melalui cara dari siswa untuk mengontrol diri dan menguasai dirinya dalam melakukan sesuatu (Ariananda dkk., 2014). Dalam hal pengendalian diri, tata tertib memegang peranan penting dalam menjalankannya, sehingga siswa memiliki tanggung jawab atas setiap perbuat yang dilakukan. Selain itu, 
kepatuhan siswa terhadap suatu aturan atau tata tertib terlihat dari bagaimana siswa menjunjung tinggi norma yang berlaku dan tetap merujuk pada peraturan yang berlaku disekolah.

Dalam melaksanakan tata tertib yang berlaku disekolah, siswa harus memiliki sikap disiplin. Sikap disiplin yang dimiliki oleh siswa akan membantu siswa dalam mengembangkan dan menentukan tujuan dari pekerjaan yang dilakukannya. Disiplin dapat dikatakan sebagai perilaku yang taat terhadap sebuah peraturan (Nurwanti dalam Sari \& Rofiyarti, 2017). Kedisiplinan sangat penting dilakukan dalah sebuah proses pembentukan karakter sebagaimana dijelaskan bahwa pendidikan karakter penting untuk kualitas suatu bangsa. Sikap disiplin sendiri berarti suatu upaya yang dikerahkan oleh tenaga pendidik untuk memberikan dorongan, semangat, dan bimbingan dalam mengontol tingkah laku seseorang dalam lingkungan sosial (Sari \& Rofiyarti, 2017)

Kaitannya dengan dunia pendidikan, disiplin merupakan salah satu aspek yang mengaturdan mempengaruhi kegiatan siswa dalam proses belajar (Sugiarto dkk., 2019). Sugiarto dkk., menambahkan juga bahwa dalam kegiatan belajar siswa dituntut untuk menyelesaikan tugas yang diberikan sesuai dengan arahan guru. Dengan kedisiplinan yang dimiliki oleh siswa dalam menyelesaikan tugasnya maka siswa juga akan memiliki cara belajar yang lebih efektif. Cara belajar yang efektif dapat dilakukan melalui pengaturan atau manajemen waktu yang baik. Membagi porsi dalam setiap kegiatan sesuai dengan prioritas yang telah disusun. Dengan bantuan seperti ini, siswa akan terbiasa dengan peraturan yang diberlakukan pada diri sendiri atau dalam cakupan peraturan yang ada disekolah.

Disiplin belajar yang dimiliki siswa tertuang dalam diisplin belajar mereka. Disiplin belajar merupakan suatu sikap patuh terhadap peraturan tertulis maupun tidak tertulis dalam proses perubahan suatu tingkah laku berupa pengalaman yang meliputi mengamati, menirukan, mencoba, mendengarakan, serta mengikuti suatu arahan atau petunjuk yang diberikan (Gunarsa dalam Sugiarto dkk., 2019). Disiplin belajar juga didefinisikan sebagai kesadaran siswa dalam pelaksanaan pembelajaran yang dilakukan tanpa adanya paksaan. Dalam disiplin belajar, terciptanya pembelajaran yang berhasil diiringi dengan pemahaman prinsip yang harus dimengerti leh semua komponen yang terlibat.

Dengan demikian, disiplin belajar dapat meningkatkan motivasi siswa dalam mengikuti pembelajaran. Disiplin belajar yang dimiliki siswa mempengaruhi cara siswa belajar dan melatih siswa untuk menghargai waktu yang dimiliki. Sugiarto dkk., (2019) dalam penilitiannya menyatakan bahwa disiplin belajar mampu membantu siswa dalam mempersiapkan sesuatu dengan lebih matang dan lebih teratur dengan waktu yang dimilikinya. Siswa yang memiliki sikap disiplin yang baik akan memiliki kesuksesan dan pengaruh yang baik dalam kehidupan bermasyarakat. Hal ini terkait dengan tujuan dari diisplin yang membuat keteraturan sesuai dengan nilai agama, budaya, aturan dalam pergaulan, pandangan hidup, serta hidup yang bermakna dalam bermasyarakat (Yuliantika, 2017).

Tata tertib dan disiplin belajar merupakan dua hal yang berkaitan dan saling mempengaruhi satu dengan yang lainnya. Pernyataan ini dibuktikan dengan beberapa penelitian yang membahas tentang tata tertib dan disiplin belajar. Yuliantika (2017) menyatakan bahwa salah satu faktor yang memepengaruh disiplin belajar pada siswa tingkat SMA yaitu penerapan tata tertib disekolah. Selain itu tata tertib sekolah juga merupakan salah satu sarana pendidikan karakter siswa (Nuriyah, 2015). Serta, kedisiplinan juga memiliki pengaru yang signifikan terhadap hasil belajar siswa. Elly (2016) mengungkapkan bahwa dalam penelitiannya, kedisiplinan memilki pengaruh terhadap keberhasilan siswa dalam pembelajaran. 4 dari 6 siswa memiliki hasil belajar yang sesuai dengan kedisiplinannya.

Namun, fenomena lain ditunjukan oleh siswa MA Al-Irsyad Candikuning II Bedugul, ditemukan bahwa masih banyak siswa yang belum mematuhi tata tertib yang diterapkan disekolah. Keseharian yang dijalani oleh siswa membuktikan bahwa banyaknya pelanggaran yang dilakukan. Beberapa contoh pelanggaran yang dilakukan yaitu tidak mengikuti proses pembelajaran, tidak mengikuti pembelajaran tanpa alasan serta tidak menggunakan surat keterangan tidak sehat yang diberikan oleh dokter. Hal ini memicu pelanggaran yang tergolong berat terhadap tata tertib yang dilakukan. Nuriyah (2015) dalam penelitiannya mengungkapkan bahwa beberapa faktor yang memicu terjadinya pelanggaran terhadap tata tertib sekolah yaitu faktir internal seperti potensi, motif, serta intelegensi pada diri siswa. Sedangkan faktor eksternal seoerti lingkungan, pendidik, materi pendidikan, serta hal yang terkai dengan proses pembelajaran.

Pelanggaran yang dilaukan oleh siswa diatasi atau diatur dengan sanksi yan diberlakukan serta tercantum dalam tata tertib. Tujuan diberlakukannya sanksi yaitu memberikan efek jera kepada pelanggar atau siswa yang melanggar aturan. Hal ini dilakukan untuk mengantisipasi terjadi pengulangan pelanggaran aturan yang dilakukan siswa. Sanksi yang diberikan dapat berupa sanksi yang tertulis dan tidak tertulis (Nuriyah, 2015). Sanksi yang dibebankan kepada siswa juga akan menyesuaikan dengan tingkatan pelanggaran yang dilakukan serta memperhatikan kondisi dari siswa tersebut. Hal ini dilakukan agar siswa memiliki tanggung jawab serta mendapatkan binaan dari sekolah. 
Berdasarkan latar belakang masalah yang ditemui, maka sangat penting untuk dilakukan sebuah peninjauan terhadap pengaruh aturan yang berlaku terhadap disiplin belajar siswa. Oleh karena itu, penelitian ini bertujuan untuk menilai pengaruh penerapan tata tertib sekolah terhadap disiplin belajar siswa di MA Al-Irsyad Candikuning Bedugul II.

\section{Metode}

Penelitian ini merupakan penelitian dengan jenis kausal yang digunakan untuk menemukan hubungan sebab akibat dari beberapa variabel. Tujuan dari penelitian ini yaitu mengetahui pengaruh penerapan tata tertib terhadao disiplin siswa MA AL-Irsyad Candikuning II Bedugul tahun ajaran 2020/2021. Variabel yang diteliti pada penelitian ini yaitu penerapan tata tertib sekolad dan disiplin belajar siswa. Sehingga pada penelitian ini melihat adanya pengaruh varial independent terhadap variabel dependen.

Populasi dan sampel yang digunakan pada penelitian ini yaitu siswa di MA Al-Irsyad Candikuning II Bedugul. Populasi pada penelitian ini yaitu seluruh siswa MA Al-Irsyad Candikuning II Bedugul. Populasi tersebut terdiri dari 76 siswa yang terbagi menjadi 46 siswa laki-laki dan 30 siswa perempuan. Persebaran populasi pada penelitian ini dapat dilihat pada tabel dibawah ini.

Tabel 1. Populasi Penelitian

\begin{tabular}{llllll}
\hline No & Jenis Kelamin & $\begin{array}{c}\text { Kelas } \\
\mathbf{X}\end{array}$ & $\begin{array}{l}\text { Kelas } \\
\text { XI }\end{array}$ & Kelas XII & Jumlah \\
\hline 1 & Laki-laki & 13 & 13 & 20 & 46 \\
2 & Perempuan & 10 & 4 & 16 & 30 \\
\hline & Total & 23 & 17 & 36 & 76 \\
\hline
\end{tabular}

Berdasarkan tabel persebaran populasi penelitian, terdapat tiga kelas yaitu kelas X. XI, dan XII dengan jumlah siswa laki-laki dan perempuan yang berbeda. Jumlah populasi yang kurang dari 100 membuat seluruh siswa di MA AL-Irsyad Candikuning II Bedugul sebagai sampel jenuh pada penelitian ini. Jadi dapat disimpulkan responden pada penelitian ini yaitu seluruh siswa MA AL-Irsyad Candikuning II Bedugul.

Metode pengumpulan data yang digunakan pada penelitian ini yaitu kuisioner. Kuisioner digunakan untuk memperoleh data terkait dengan pengaruh penerapan tata tertib terhadap disiplin belajar siswa. Pada kuisioner yang akan disebar kepada seluruh responden terdapat skala Likert yang digunakan untuk mempermudah responden dalam menentukan atau mengukur persepsi mereka. Dalam kuisioner yang disebar terdapat lima nilai pada skala Likert yaitu nilai 5 untuk jawaban “Sangat Setuju (SS)”, nilai 4 untuk jawaban "Setuju (S)", nilai 3 untuk jawaban "Ragu-ragu (RG)”, nilai 2 untuk jawaban “Tidak Setuju (TS)", dan nilai 1 untuk jawaban "Sangat Tidak Setuju (STJ)".

Data yang telah diperoleh kemudian dilanjutkan kedalam proses pengujian. Uji yang dilakukan yaitu uji validitas dan uji reliabilitas instrument yang digunakan. Kedua pengujian yang dilakukan untuk menilai kelayakan suatu instrumen yang digunakan dalam peneltiian ini. Selanjutnya, tahap yang akan dilewati yaitu analisi data. Metode analisi data yang digunakan pada penelitian ini yaitu analisis regresi linier sederhana.

\section{Hasil dan pembahasan}

\section{a. Hasil Penelitian}

Berdasarkan hasil penelitian yang telah dilakukan serta analisis data dengan bantuan SPPS versi 2-.0 for windows serta menggunakan taraf signifikan 5\% maka didapatkan hasil sebagai berikut:

Tabel 2. Hasil uji t pengaruh penerapan tata tertib sekolah terhadap disiplin belajar siswa

\begin{tabular}{|c|c|c|c|c|c|c|}
\hline \multirow{2}{*}{\multicolumn{2}{|c|}{ Model }} & \multicolumn{2}{|c|}{$\begin{array}{c}\text { Unstandardized } \\
\text { Coefficients }\end{array}$} & \multirow{2}{*}{$\begin{array}{c}\text { Standardized } \\
\text { Coefficients } \\
\text { Beta } \\
\end{array}$} & \multirow[t]{2}{*}{$\mathrm{t}$} & \multirow[t]{2}{*}{ Sig. } \\
\hline & & $\mathrm{B}$ & Std. Error & & & \\
\hline \multirow[t]{2}{*}{1} & (Constant) & 11,178 & 3,901 & & 2,865 & 0,005 \\
\hline & $\begin{array}{l}\text { Tata tertib } \\
\text { sekolah }\end{array}$ & 0,723 & 0,157 & 0,471 & 4,595 & 0,000 \\
\hline
\end{tabular}


Berdasarkan tabel 2 diketahui bahwa nilai thitung 4,595 $>t_{\text {tabel }}$ 1.992. hasil pada perhitungan analisis ini menunjukan bahwa $\mathrm{H}_{0}$ ditolak dan $\mathrm{H}_{\mathrm{a}}$ diterima. Sehingga dapat disimpulkan bahwa terdapat pengaruh terhadap disiplin belajar siswa yang disebabkan oleh penerapan tata tertib di MA Al-Irsyad Candikuning II Bedugul pada tahun ajaran 2020-2021.

Tabel 3. Hasil koefisien determinas (R2)

\begin{tabular}{lllll}
\hline Model & R & R Square & Adjusted R Square & Std. Error of the Estimate \\
\hline 1 & $0,471^{\mathrm{a}}$ & 0,222 & 0,211 & 2,825 \\
\hline
\end{tabular}

Berdasarkan hasil anailisi pada tabel 3 yang menunjukan bahwa nila R Square adalah 0,222 atau setara denga 22,2\%. Angka pada tabel menunjukan bahwa besaran variabel X atau penerapan tata tertib sekolah berpengaruh sebesar $22,2 \%$ terhadap disiplin belajar siswa. Hasil ini juga menunjukan bhawa terdapat faktor lain yang mempengaruhi kedisiplinan belajar siswa. Namun, pada penelitian ini terfokus pada penerapan tata tertib sekolah saja. Faktor lain yang menyebabkan disiplin siswa dalam belajar sebesar $77,8 \%$.

Tabel 4. Hasil uji regresi pengaruh penerapan tata tertib sekolah terhadap disiplin belajar siswa

\begin{tabular}{llcrrrr}
\hline \multirow{2}{*}{ Model } & \multicolumn{2}{c}{$\begin{array}{c}\text { Unstandardized } \\
\text { Coefficients }\end{array}$} & Standardized Coefficients & t & Sig. \\
\cline { 3 - 5 } & & B & Std. Error & Beta & & \\
\hline \multirow{2}{*}{1} & (Constant) & 11,178 & 3,901 & & 2,865 & 0,005 \\
& Tata tertib & 0,723 & 0,157 & 0,471 & 4,595 & 0,000 \\
& sekolah & & & & & \\
\hline
\end{tabular}

Berdasarkan hasil analisis mengenai persamaan regresi pengaruh penerapan tata tertib sekolah terhadap disiplin belajar siswa yang terlihat pada tabel menunjukan bahwa adanya pengaruh positif variabel $\mathrm{X}$ atau tata tertib sekolah terhadap variabel $\mathrm{Y}$ atau disiplin belajar siswa.

\section{b. Pembahasan}

Berdasarkan hasil penelitian terkait dengan pengaruh variabel terikat yaitu tata tertib sekolah terhadap variabel bebas yaitu disiplin belajar siswa MA Al-Irsyad Candikuning II Bedugul mengungkap bahwa terdapat pengaruh yang signifikan antara penerapan tata tertib sekolah terhadap disiplin belajar siswa. Hasil analisis juga menunjukan bahwa terdapat pengaruh positif dari tata tertib yang diterapkan sekolah terhadap disiplin belajar yang dijalankan oleh siswa. Selain itu, hasil yang positif dan signifikan berpengaruh sangat besar terhadap peningkatan kedisiplinan siswa khususnya dalam kegiatan pembelajaran, Sehingga siswa memiliki tanggung jawab terhadap kegiatan yang dilakukannya.

Pada dasarnya pembelajaran yang diikuti oleh disiplin belajar yang baik merupakan suatu sikap yang ditunjukan siswa dengan ketaatan dan kepatuhan demi tercapainya hasil belajar yang maksimal. Siswa yang memiliki kecenderungan diisplin belajar yang baik mampu mengendalikan diir serta mengontrol diri dalam menyelesaikan tugas. Selain itu, siswa yang memiliki disiplin belajar yang baik mampu mengatur waktu sehingga diperoleh hasil yang maksimal dengan persiapan dalam melakukan suatu hal dengan lebih matang. Hal tersebut dapat ditunjukan melalui bagaimana siswa dalam mentaati dan mematuhi tata tertib yang berlaku disekolah.

Pengaruh positif yang ditunjukan disebabkan oleh kesadaran siswa serta peran guru terhadap penerapan tata tertib sekolah. Guru memiliki peranan penting untuk menjaga siswa agar tetap bertingkah laku sesuai dengan aturan dan norma yang berlaku. Siswa yang memiliki kesadaran terhadap pentingnya disiplin utamanya dalam proses pembelajaran akan menunjukan sikap positif baik untuk diri sendiri, sekolah, maupun lingkungannya. Sikap yang ditunjukan oleh siswa akan berpengaruh terhadap kesuksesannya dimasa kini dan dimasa yang akan mendatang. Hal ini selaras dengan pendapat Rimm (dalam Elly, 2016) yang menyatakan bahwa disiplin bertujuan untuk mengarahkan anak dalam hal ini siswa untuk belajar tentang hal-hal baik yang berguna dimasa dewasanya. 
Selain peran siswa dan guru dalam penerapan tata tertib disekolah, peran lingkungan sekolah serta keluarga sebagai pondasi dalam pembentukan karakter sangatlah penting. Yana dan Nurjanah (2004) menegaskan bahwa lingkungan sekolah merupakan tempat kedua untuk siswa. Sekolah menjadi tempat kedua sebagai perpanjangan tangan dengan guru sebagai pengganti dari orang tua serta tempat siswa untuk memperoleh ilmu. Selain itu, aturan yang diberlakukan disekolah atau tata tertib yang ada disekolah tentunya memiliki perbedaan diantara keduanya. Namun, tujuan dari adanya peraturan akan tetap sama yaitu untuk dipatuhi serta ditaati sebagai pedoman dalam melakukan sesuatu.

Namun, sesungguhnya banyak faktor yang dapat mempengaruhi kedisiplinan siswa dalam belajar. Kesuksesan seseorang dalam belajar tidak luput dari beberapa hal yang dapat mengurangi kualitas dalam proses pembelajaran. Hal yang mempengaruhi seseorang dalam proses pembelajaran bisa muncul dari dalam diri maupun dari lingkungan sekitar siswa. Faktor tersebut dapat diatasi dengan mencari solusi yang terkait dengan permasalahan yang dijalani.

Faktor yang dapat mempengaruhi yaitu faktor internal dan faktor eksternal. Faktor internal merupkan faktor yang mempengaruhi disiplin belajar siswa yang datang atau ada pada diri siswa itu sendiri, Sedangkan faktor eksternal merupakan faktor yang berasal dari luar diri siswa. Hasil yang diperoleh pada penelitian ini menunjukan bahwa salah satu faktor eksternal yang mempengaruhi disiplin siswa yaitu tata tertib. Adapun indikator yang termasuk kedalam tata tertib sekolah yaitu tugas dan kewajiban, larangan bagi para siswa, serta sanksi yang mengikat jika terjadi pelanggaran terhadap tata tertib yang berlaku (Nawawi dalam Hadianti, 2008). Tata tertib disusun sesuai dengan kebutuhan setiap siswa sehingga menyesuaikan dengan kondisi dan situasi disetiap sekolah.

Hasil pada penelitian saat yang menunjukan pengaruh positif tata tertib sekolah terhadap disiplin belajar siswa di MA Al-Irsyad Candikuning II Bedugul juga memperoleh hasil yang sama dengan penelitian terdahulu. Yuliantika (2017) dalam penelitiannya mengungkapkan bahwa salah satu faktor yang mempengaruhi disiplin siswa dalam belajar yaitu penerapan tata tertib sekolah. Hal ini terjadi karena sekolah merupakan lingkungan yang membentuk karakter siswa setelah lingkungan keluarga. Dia juga mengungkapkan bahwa penerapan tata tertib sekolah juga tergantung pada profesionalitas guru yang melakukan pembinaan terhadap siswa sebagai sarana pendukung penerapan tata tertib sekolah. Selain itu hal-hal yang terkait dengan proses pembelajaran menjadi faktor dalam penerapan tata tertib disekolah.

Hadianti (2008) pada penelitiannya tentang pengaruh tata tertib sekolah terhadap kedisiplinan belajar siswa di SDN Sukakarya II semarang juga mengungkapkan bahwa faktor yang mempengaruhi kedisplinan siswa dalam belajar salah satunya yaitu penerapan tata tertib seklah. Pada penelitian yang dilakukannya, tata tertib berpengaruh sebesar 39\% terhadap disiplin belajar siswa. Jumlah tersebut lebi besar dari hasil yang diperoleh pada penellitian saat ini. Penelitian saat ini menunjukan bahwa tat tertib berpengaruh sebesar $22,2 \%$ terhadap disiplin belajar siswa. Selanjutnya, kedua penelitian ini menyatakan bahwa masih banyak faktor lain yang berpengaruh terhadap disiplin belajar siswa namun tidak termasuk kedalam variabel penelitian.

Selain itu, penerapan tata tertib juga dapat dikatan sebagai saran untuk membentuk karakter siswa. Dengan mentaati peraturan yang berlaku siswa akan memiliki karakter yang baik serta kedisiplinan yang tinggi. Karakter yang dimiliki siswa dapat ditunjukan dengan penyelesaian tugas dan kewajiban yang termuat dalam tata tertib sekolah. Octavia (2017) mengungkapkan bahwa penerapan tata tertib sekolah berpengaruh pada pembentukan moral siswa dengan dipengaruhi faktor pendidik, lingkungan sekolah, serta diri siswa itu sendiri. Kedisiplinan dapat dikatan sebagai salah satu moral yang harus dimiliki siswa. Sehingga tata tertib disekolah sangat dibutuhkan sebagai sarana untuk membiasakan siswa dalam bertingkah laku sesuai dengan norma dan aturan yang berlaku.

\section{Simpulan}

Dalam mendisiplinkan siswa untuk belajar, banyak faktor yang mempengaruhi. Terdapat faktor eksternal dan internal. Faktor eksternal merupakan faktor yang berasala dari luar diri siswa. Faktor eksternal meliputi lingkungan sekolah, pendidik, dan tata tertib. Sedangkan, faktor internal dapat didefinisikan sebagai faktor yang mempengaruhi siswa yang berasal dari diri siswa itu sendiri. Faktor internal meliputi kondidi fisik dan psikis siswa. Oleh karena out, pada peneltiian ini terfokus pada salah satu faktor eksternal yang mempengaruhi disiplin belajar siswa yaitu penerapan tata trtib sekolah.

Tata tertib merupakan suatu aturan yang dirancang oleh sekolah dengan tujuan untuk membiasakan serta mendisiplinkan siswa. Selain itu, tata tertib juga berguna untuk mengarahkan siswa kepada hal yang positif. Dengan aturan yang dirancang, siswa akan mentaati serta mematuhi peraturan yang berlaku. Dalam tata tertib disekolah terdapat tiga aspek yang meliputi tugas dan kewajiban siswa, larangan-larangan bagi para siswa, serta sanksi yang dibebankan kepada siswa jika terjadi pelanggaran terhadap tata tertib sekolah. Tata tertib sekolah memiliki pengaruh yang baik untuk kedisiplinan siswa dalam belajar. 
Kedisiplinan siswa dalam belajar dapat dimulai melalui peraturan terhadap penyelesaian tugas siswa. Dengan hal tersebut siswa dapat melatih sikap tanggung jawab terhadap hal yang dilakukannya.

Penerapan tata tertib disekolah dapat dijalankan dengan baik jika adanya kerjasama antara siswa, guru, serta tenaga pendidik lainnya. Guru sebagai fasilitator dapat memberikan binaan terhadap siswa untuk dapat mematuhi peraturan yang telah dirancang. Dengan begitu siswa sapat mengontrol tingkah laku serta diri sendiri. Peran guru sangat dibutuhkan karena guru merupakan oran tua untuk siswa disekolah. Serta, sekolah menjadi lingkungan kedua bagi siswa untuk menimba ilmu serta membentuk karakter diri. Karakter serta disiplim belajar yang baik merupakan dua hal yang mampu menentukan kesuksesan seseorang dimasa kini dan dimasa yang akan datang.

Berdasarkan hasil analisis yang telah dilakukan, dapat disimpulkan bahwa tata tertib memiliki peran yang sangat penting dalam proses pembelajaran. Peran tata tertib yang sangat penting didukung dengan penerapannya dalam proses pembelajaran. Hal ini akan berpengaruh pada hasil dan disiplin belajar siswa. Pada penelitian saat ini membuktikan bahwa tata tertib berpengaruh sebesar $22,2 \%$ terhadap disiplin belajar siswa. Terdapat dua faktor yang dapat mempengaruhi disiplin belajar siswa diantaranya faktor internal dan eksternal. Tata tertib sekolah merupakan satu dari beberapa faktor eksternal yang mampu mempengaruhi kedisiplinan siswa dalam belajar. Sehingga jumlah besaran faktor lainnya yang mempengaruhi disiplin belajar siswa di MA Al-Irsyad Candikuning II Bedugul tahun ajaran 2020/2021 sebesar $77,8 \%$.

Berdasarkan simpulan penelitian, peneliti memberikan saran kepada guru, kepala sekolah, serta peneliti selanjutnya. Adapun Saran yang diberikan yaitu a) guru diharapkan untuk dapat memaksimalkan peran tata tertib guna mendisiplinkan siswa serta mengontrol tingkah laku siswa agar sesuai dengan norma dan aturan yang berlaku, serta meminimalisir terjadinya pelanggaran tata tertib sekolah, b) Kepala Sekolah diharapkan bisa melakukan evaluasi terhadap penerapan tata tertib sekolah sehingga dapat meningkatkan disiplin siswa dan juga dapat melengkapi sarana dan prasarana pendukung penerapan tat tertib sekolah, c) peneliti selanjutnya diharapkan bisa menggunakan penelitian saat ini sebagai referensi untuk penelitian lebih lanjut serta memperluas cakupan penelitian agar mendapatkan hasil yang lebih relevan. Saran yang diberikan kepada guru, kepala sekolah, serta peniliti merupakan saran yang diharapkan dapat memotivasi untuk mengembangkan penelitian selanjutnya dengan hasil yang lebih maksimal.

\section{Daftar Rujukan}

Ariananda, E. S., Hasan, S., \& Rakhman, M. (2014). Pengaruh kedisiplinan siswa disekolah terhadap prestasi belajar siswa teknik pendingin. Journal of Mechanical Engineering Education, 1(2), 233-238. https://doi.org/10.17509/jmee.v1i2.3805

Elly, R. (2016). Hubungan kedisiplinan terhadap hasil belajar siswa kelas V di SD Negeri 10 Banda Aceh. Jurnal Pesona Dasar, 3(4), 43-53.

Hadianti, L. S. (2008). Pengaruh pelaksanaan tata tertub sekolah terhadap kedisiplinan belajar siswa (penelitian deskriftif analisis di SDN Sukakarya II Kecamatan Semarang Kabupaten Garut). Jurnal Pendidikan Universitas Garut, 02(1), 1-8.

Nuriyah, E. S. (2015). Tata tertib sekolah sebagai sarana pendidikan karakter di SDN Pekuwon III Sumberejo tahun pelajaran 2011/2012. Jurnal Pendidikan Edutama, 2(1), 50-62.

Octavia, E. (2017). Analisis pelaksanaan tata tertib sekolah sebagai sarana pembinaan moral di SMA Taman Mulya Kecamatan Sungai Raya. Jurnal Pendidikan Kewarganegaraan, 1(1), 14-24.

Sari, A. Y., \& Rofiyarti, F. (2017). Penerapan disiplin sebagai bentuk pembinaan pendidikan karakter terhadap anak usia dini. PEDAGOGI: Jurnal Anak Usia DIini Dan Pendidikan Anak Usia Dini, 3(3), 227 239.

Sugiarto, A. P., Suyati, T., \& Yulianti, P. D. (2019). Faktor kedisiplinan belajar pada siswa kelas X SMK Larenda Brebes. Jurnal Mimbar Ilmu, 24(2), 232-238. https://doi.org/10.23887/mi.v24i2.21279

Yana, E., \& Nurjanah, N. (2004). Pengaruh lingkungan keluarga dan lingkungan sekolah terhadap prestasi belajar siswa pada mata pelajaran ekonomi di kelas XI IPS SMA Negeri 1 Ciledug Kabupaten Cirebon. Edunomic Jurnal Pendidikan Ekonomi, 2(1). https://doi.org/10.6009/jjrt.KJ00003534360

Yuliantika, S. (2017). Analisis faktor-faktor yang mempengaruhi disiplin belajar siswa kelas X,XI, dan XII di SMA Bhakti yasa Singaraja tahun pelajaran 2016/2017. Jurnal Pendidikan Ekonomi Undiksha, 9(1), 35-44. https://doi.org/10.23887/jjpe.v9i1.19987 